\title{
Chlorine chemistry and the potential for ozone depletion in the arctic stratosphere in the winter of 1991/92
}

\author{
R. Müller, ${ }^{1}$ Th. Peter, ${ }^{1}$ P. J. Crutzen, ${ }^{1}$ H. Oelhaf, ${ }^{2}$ G. P. Adrian, ${ }^{2}$ Th. v. Clarmann, ${ }^{2}$ \\ A. Wegner, ${ }^{2}$ U. Schmidt, ${ }^{3}$ and D. Lary ${ }^{4}$
}

\begin{abstract}
We present an analysis of chlorine chemistry in the Arctic stratosphere during the winter of $1991 / 92$ and assess its potential implications for ozone depletion. In accordance with observations of total organic chlorine, $\mathrm{ClONO}_{2}$ and $\mathrm{HCl}$, box model results indicate the following: (1) An almost complete activation of chlorine during the cold winter period. (2) A possible contribution from the heterogeneous reaction $\mathrm{HOCl}+\mathrm{HCl}$ and the gas-phase reaction $\mathrm{CH}_{3} \mathrm{O}_{2}+$ $\mathrm{ClO}$ to the complete conversion of $\mathrm{HCl}$ to active chlorine (3) A strong buildup of $\mathrm{ClONO}_{2}$ following PSC disappearance which remains the main chlorine reservoir for about a month, after which $\mathrm{HCl}$ becomes dominant. (4) Appreciable chemical ozone loss in the lower stratosphere inside the polar vortex is conceivable for the winter of 1991/92.
\end{abstract}

\section{Introduction}

One objective of the European Arctic Stratospheric Ozone Experiment (EASOE) was to provide a wide spatial and temporal coverage of measurements of chemical species in the polar stratosphere. Here, we use several of these measurements in an attempt to provide a synoptic view of the chemical evolution of chlorine and nitrogen species in the Arctic lower stratosphere during the winter of 1991/92.

Ground-based observations of total column $\mathrm{ClONO}_{2}$ over the entire winter [Adrian et al., 1994], along with balloonborne observations of $\mathrm{ClONO}_{2}$ inside the vortex on January 13, 1992 and March 14, 1992 [v. Clarmann et al., 1993; Oelhaf et al., 1994], indicate a sizable conversion of this species to active chlorine during the coldest period from the end of December to the end of January, followed by an almost complete transformation of the available chlorine to $\mathrm{ClONO}_{2}$ during the beginning March. Moreover, groundbased observations of very low column densities of $\mathrm{HCl}$ during the winter and spring of 1992 [Adrian et al., 1994; Bell et al., 1994] suggest a substantial conversion of $\mathrm{HCl}$ to active chlorine.

In order to analyze the mechanisms responsible for the exceptional, unprecedented observations of chlorine species we conducted chemical box model calculations for air parcels representative of the conditions in the Arctic vortex in 1991/92. Encouraged by the ability of our model to repro-

\footnotetext{
${ }^{1}$ MPI for Chemistry, Atmospheric Chemistry Dep. Mainz, Germany

${ }^{2}$ Inst. Meteorol. Climate Res., KFK, Karlsruhe, Germany

${ }^{3}$ KFA Jülich, Jülich, Germany

${ }^{4}$ Dep. of Chemistry, University of Cambridge, Cambridge, UK
}

Copyright 1994 by the American Geophysical Union.

Paper number 94GL00465

0094-8534/94/94GL-00465\$03.00 duce the principal features the disturbed chlorine chemistry in accordance with the observations, we further investigated the potential consequences of the simulated high levels of active chlorine for ozone loss.

\section{Model description}

We use a chemical box model [Crutzen et al., 1992] including a complete set of gas-phase and heterogeneous reactions, the latter both on liquid sulfuric acid and nitric acid trihydrate (NAT) surfaces (Table 1). In the model, NAT particles form at $3 \mathrm{~K}$ supercooling, as indicated by observations in the Arctic [Schlager et al., 1990; Dye et al., 1992]. For the computation of the photolysis rates, a scheme was adopted that accurately describes photolysis at large solar zenith angles [Lary and Pyle, 1991] and includes the temperature depen-

Table 1. Reactions important to this work

\begin{tabular}{|c|c|c|c|c|}
\hline & Reaction & & & $\gamma$ \\
\hline H1 & $\mathrm{N}_{2} \mathrm{O}_{5}+\mathrm{H}_{2} \mathrm{O}$ & $\rightarrow$ & $2 \mathrm{HNO}_{3}$ & 0.0006 \\
\hline $\mathbf{H} 2$ & $\mathrm{ClONO}_{2}+\mathrm{H}_{2} \mathrm{O}$ & $\rightarrow$ & $\mathrm{HOCl}+\mathrm{HNO}_{3}$ & 0.006 \\
\hline H3 & $\mathrm{ClONO}_{2}+\mathrm{HCl}$ & $\rightarrow$ & $\mathrm{Cl}_{2}+\mathrm{HNO}_{3}$ & 0.3 \\
\hline H4 & $\mathrm{HOCl}+\mathrm{HCl}$ & $\rightarrow$ & $\mathrm{Cl}_{2}+\mathrm{H}_{2} \mathrm{O}$ & 0.1 \\
\hline H5 & $\mathrm{N}_{2} \mathrm{O}_{5}+\mathrm{HCl}$ & $\rightarrow$ & $\mathrm{ClNO}_{2}+\mathrm{HNO}_{3}$ & 0.003 \\
\hline \multicolumn{5}{|c|}{ Rate const. } \\
\hline R1 & $\mathrm{Cl}+\mathrm{CH}_{4}$ & $\rightarrow$ & $\mathrm{HCl}+\mathrm{CH}_{3}$ & $1.0(-14)$ \\
\hline $\mathbf{R} 2$ & $\mathrm{ClO}+\mathrm{NO}_{2}+\mathrm{M}$ & $\rightarrow$ & $\mathrm{ClONO}_{2}+\mathrm{M}$ & $1.6(-12)$ \\
\hline R3 & $\mathrm{ClO}+\mathrm{HO}_{2}$ & $\rightarrow$ & $\mathrm{HOCl}+\mathrm{O}_{2}$ & $1.6(-11)$ \\
\hline R4 & $\mathrm{Cl}+\mathrm{O}_{3}$ & $\rightarrow$ & $\mathrm{ClO}+\mathrm{O}_{2}$ & $7.9(-12)$ \\
\hline R5 & $\mathrm{ClO}+\mathrm{NO}$ & $\rightarrow$ & $\mathrm{Cl}+\mathrm{NO}_{2}$ & $2.7(-11)$ \\
\hline R6 & $\mathrm{ClO}+\mathrm{O}$ & $\rightarrow$ & $\mathrm{Cl}+\mathrm{O}_{2}$ & $4.3(-11)$ \\
\hline R7 & $\mathrm{HNO}_{3}+h \nu$ & $\rightarrow$ & $\mathrm{NO}_{2}+\mathrm{OH}$ & $4.7(-8)$ \\
\hline R8 & $\mathrm{HNO}_{3}+\mathrm{OH}$ & $\rightarrow$ & $\mathrm{NO}_{3}+\mathrm{H}_{2} \mathrm{O}$ & $5.4(-13)$ \\
\hline R9 & $\mathrm{ClONO}_{2}+h \nu$ & $\rightarrow$ & $\mathrm{Cl}+\mathrm{NO}_{3}$ & $1.8(-5)$ \\
\hline $\mathbf{R} 10$ & $\mathrm{ClO}+\mathrm{CH}_{3} \mathrm{O}_{2}$ & $\rightarrow$ & $\mathrm{Cl}+$ prod. & $1.0(-12)$ \\
\hline R11 & $\mathrm{ClO}+\mathrm{ClO}+\mathrm{M}$ & $\rightarrow$ & $\mathrm{Cl}_{2} \mathrm{O}_{2}+\mathrm{M}$ & $2.7(-13)$ \\
\hline R12 & $\mathrm{Cl}_{2} \mathrm{O}_{2}+\mathrm{M}$ & $\rightarrow$ & $\mathrm{ClO}+\mathrm{ClO}+\mathrm{M}$ & $3.9(-5)$ \\
\hline $\mathbf{R} 13$ & $\mathrm{Cl}_{2} \mathrm{O}_{2}+\mathrm{h} \nu$ & $\rightarrow$ & $\mathrm{ClOO}+\mathrm{Cl}$ & $7.1(-4)$ \\
\hline R14 & $\mathrm{ClO}+\mathrm{BrO}$ & $\rightarrow$ & $\mathrm{Cl}+\mathrm{Br}+\mathrm{O}_{2}$ & $8.7(-12)$ \\
\hline
\end{tabular}

For the heterogeneous reactions $\mathrm{H} 1-\mathrm{H} 5$, reaction probabilities $\gamma$ for NAT [DeMore et al., 1992] are listed. On sulfuric acid (with weight percentage W) only $\mathrm{H1}(\gamma=0.1)$ and $\mathrm{H} 2\left(\gamma=10^{1.86-00747 \cdot \mathrm{W}}\right)$ were included [Hanson and Ravishankara, 1991]. For the gas-phase reactions R1-R14, rate constants (in $\mathrm{cm}^{3} \mathrm{~s}^{-1} \mathrm{molec}^{-1}$; except R12 in s${ }^{-1}$ ) [DeMore et al., 1992] for 100 mbar and $200 \mathrm{~K}$ and photolysis rates (in $\mathrm{s}^{-1}$ ) for $85^{\circ}$ zenith angle are given. 


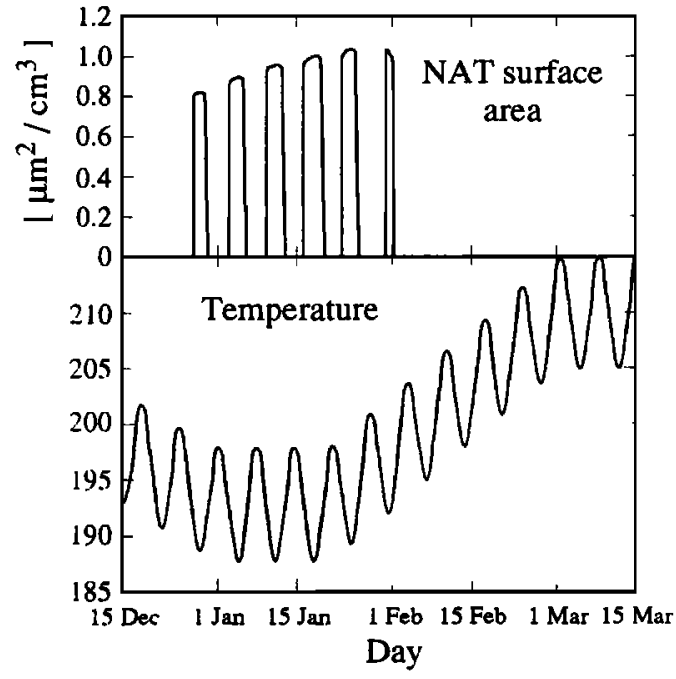

Figure 1. The adopted temperature history and the NAT surface area (in $\mu \mathrm{m}^{2} / \mathrm{cm}^{3}$ ) over the model period December 15, 1991 to March 15, 1992.

dence of the UV-cross sections for $\mathrm{HNO}_{3}$ [Burkholder et al., 1993]. We use one quarter of the recommended upper limit [DeMore et al., 1992] as reaction rate for R10. A rate of this order has recently been substantiated by measurements which further disclosed $\mathrm{CH}_{3} \mathrm{OCl}$ as a product of $\mathrm{R} 10$ [Helleis et al., 1993].

The temperature history (Fig. 1), of the air parcels inside the polar vortex in the lower stratosphere during the winter of 1991/92 was estimated from observations [Naujokat and Labitzke, 1993; Waters et al., 1993]. Further, to simulate the diabatic descent in the vortex indicated by observations of inert tracers [Schmidt et al., 1993], they are assumed to sink from $550 \mathrm{~K}$ to $450 \mathrm{~K}(22-17 \mathrm{~km})$ over the model period. Some simulations have also been performed for different height levels to estimate total column amounts. The air parcels are either constrained to constant latitude $\left(58^{\circ} \mathrm{N}-78^{\circ} \mathrm{N}\right)$, or sinusoidal variations in latitude $\left(68^{\circ} \pm 10^{\circ} \mathrm{N}\right)$ were prescribed. In accordance with meteorological observations, the cooling episodes and the southward excursions are assumed to take place over northern Europe.

There are some limitations in using a box model in this, highly idealized way, and, consequently, a detailed, quantitative comparison with measurements is not attempted. Nonetheless, since the model assumptions are representative of the situation inside the polar vortex in the winter 1991/92, some conclusions about the chemical mechanisms at work may be drawn on account of the model results.

\section{Model results and observations}

Chlorine and nitrogen species. In the model, NAT particles exist from the end of December to the end of January (Fig. 1) in accordance with estimates based on a thorough meteorological analysis [Newman et al., 1993] and lidar measurements [Stein et al., 1993]. The surfaces of these particles catalyze the heterogeneous reactions $\mathrm{H} 3-\mathrm{H} 5$ that activate $\mathrm{HCl}$. While $\mathrm{H} 5$ is unlikely to be very effective due to prior removal of $\mathrm{N}_{2} \mathrm{O}_{5}$ by reaction on sulfate aerosol particles via $\mathrm{H} 1$, reactions $\mathrm{H} 3$ and $\mathrm{H} 4$ proceed rapidly, effectively titrating the available $\mathrm{ClONO}_{2}$ and $\mathrm{HOCl}$ against $\mathrm{HCl}$ on a timescale of hours (Fig. 2). The further depletion in $\mathrm{HCl}$ is much slower and is controlled by the supply of reaction partners for $\mathrm{HCl}$. The most important partner under sunlight conditions and when PSCs exist is $\mathrm{HOCl}$ produced via R3. Further, whenever PSCs evaporate during warm periods (Fig. 1), $\mathrm{HNO}_{3}$ is released into the gas-phase and $\mathrm{ClONO}_{2}$ recovers via $\mathrm{R} 2$ (Fig. 2), thereby using up the $\mathrm{NO}_{x}$ produced by $\mathrm{R} 7$ and R8. Thus, $\mathrm{NO}_{2}$ concentrations remain low. Similarly, in PSCfree periods, $\mathrm{HOCl}$ builds up via reaction R3 (Fig. 3). With the PSCs reappearing during cold periods, $\mathrm{HCl}$ is removed via $\mathrm{H} 3$ and $\mathrm{H} 4$ with $\mathrm{ClONO}_{2}$ and $\mathrm{HOCl}$ being about equally important. Since the buildup of $\mathrm{HCl}$ during the warm periods is much slower than that of $\mathrm{HOCl}$ and $\mathrm{ClONO}_{2}$ (see below), the recurrent evaporation of PSCs thus enhances the depletion of $\mathrm{HCl}$. In the model, $\mathrm{HCl}$ is severely depleted in the lower stratosphere, a finding supported by the very low column amounts of $\mathrm{HCl}$ measured at the end of January. The $\mathrm{ClONO}_{2}$ concentrations remain extremely low in the model throughout the period when PSCs exist, in good accordance with the balloon-borne observation on January 13 .

After the last PSCs disappear in the model simulation, the active chlorine is almost completely converted to $\mathrm{ClONO}_{2}$

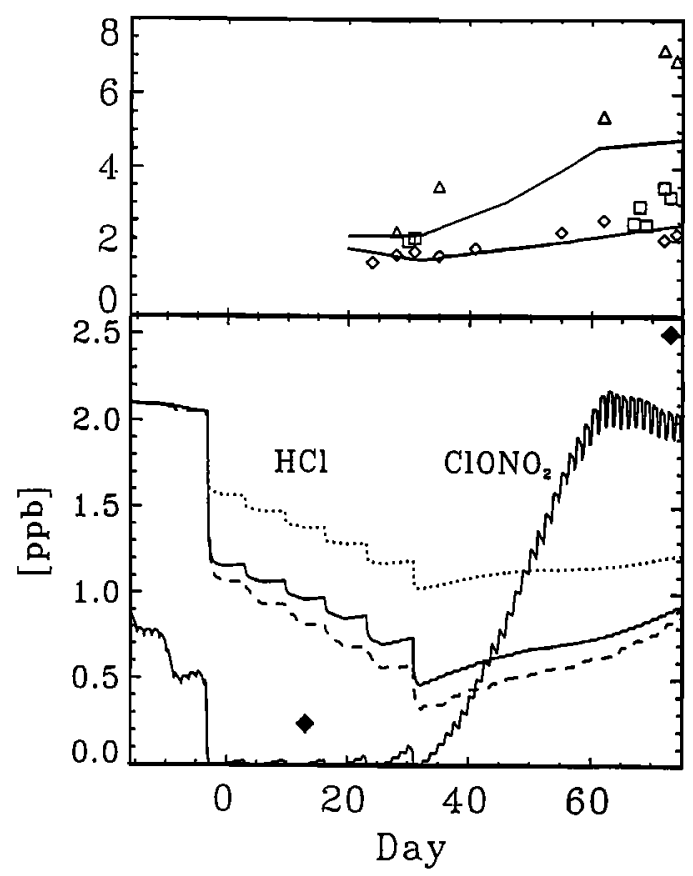

Figure 2. The main chlorine reservoirs over the model period: Upper panel shows the FTIR observations of stratospheric $\mathrm{HCl}$ column amounts over Kiruna (diamonds) and Greenland (squares) and $\mathrm{ClONO}_{2}$ total column amount over Kiruna (triangles) (see Adrian et al. [1994] for details); also column densities of $\mathrm{HCl}$ (thick solid line) and $\mathrm{ClONO}_{2}$ (thin solid line) derived from the model results are shown (all in $10^{15} \mathrm{~cm}^{-2}$ ). Lower panel shows $\mathrm{HCl}$ and $\mathrm{ClONO}_{2}$ mixing ratio in the lower stratosphere from the model results (at $68^{\circ} \mathrm{N}$ ), dotted line shows simulated $\mathrm{HCl}$ neglecting reactions $\mathrm{H} 4$ and R10, dashed line the results allowing excursions in latitude. Diamonds in the lower panel indicate the mixing ratios of $\mathrm{ClONO}_{2}$ on March 14, 1992, (about $17 \mathrm{~km}$ height) and on January 13, 1992 (about $18 \mathrm{~km}$ height), both observed by MIPAS-B. 


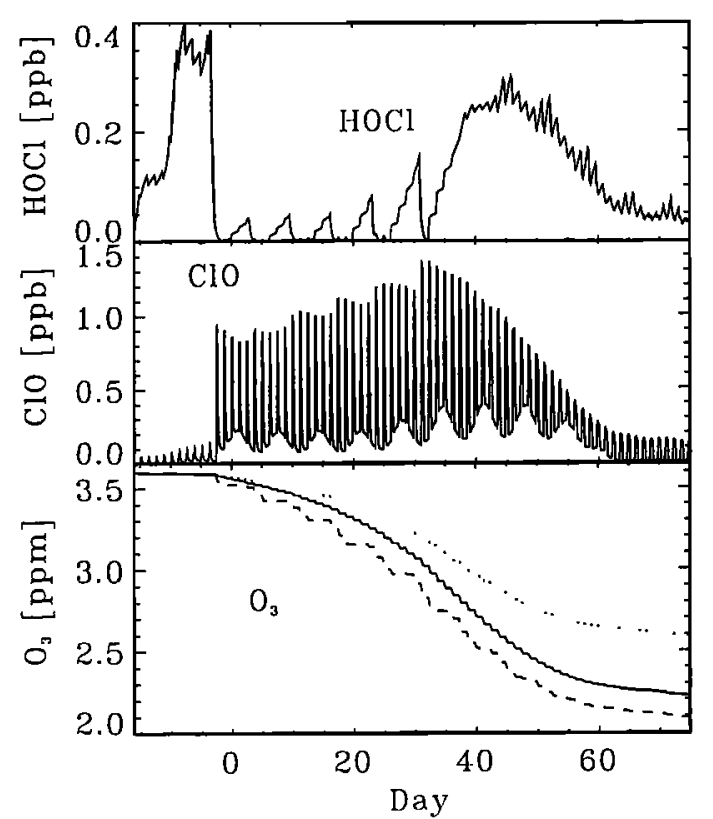

Figure 3. The mixing ratios of $\mathrm{HOCl}, \mathrm{ClO}$ and ozone in the lower stratosphere (at $68^{\circ} \mathrm{N}$ ) over the model period. Dotted line in lower panel indicates ozone simulated neglecting reactions $\mathrm{H} 4$ and $\mathrm{R} 10$, dashed line the results allowing excursions in latitude.

via $\mathrm{R} 2$; the recovery of $\mathrm{HCl}$ via $\mathrm{R} 1$ is much slower (Fig. 2). This pattern is clearly borne out by measurements which show (in agreement with the model) extremely high column amounts of $\mathrm{ClONO}_{2}$, yet only a slow recovery of $\mathrm{HCl}$ towards the end of winter (Fig. 2). It is further corroborated by the balloon-borne observation on March 14 which shows very high mixing ratios of $\mathrm{ClONO}_{2}$ in the lower stratosphere.

The reason for the preferred production of $\mathrm{ClONO}_{2}$ over $\mathrm{HCl}$ can be explained by the relative effectiveness of reactions R1 and R2 for the removal of active chlorine:

$$
\alpha=\frac{d[\mathrm{HCl}] / d t}{d\left[\mathrm{ClONO}_{2}\right] / d t}=\frac{k_{1}\left[\mathrm{CH}_{4}\right]}{k_{2}\left[\mathrm{NO}_{2}\right]} \frac{[\mathrm{Cl}]}{[\mathrm{ClO}]} \approx \frac{k_{1}\left[\mathrm{CH}_{4}\right] k_{5}[\mathrm{NO}]}{k_{2}\left[\mathrm{NO}_{2}\right] k_{4}\left[\mathrm{O}_{3}\right]}
$$

Assuming $\mathrm{NO} / \mathrm{NO}_{2} \approx 1$ and mixing ratios of $\mathrm{O}_{3}$ and $\mathrm{CH}_{4}$ in the ppmv range, $\alpha \approx 10^{-2}$, and thus practically all the active chlorine will initially be converted into $\mathrm{ClONO}_{2}$. The rate of increase in $\mathrm{ClONO}_{2}$, and thus the rate of chlorine deactivation, is controlled by the rate of release of $\mathrm{NO}_{2}$ from the $\mathrm{HNO}_{3}$ via $\mathrm{R} 7$ and $\mathrm{R} 8$ after the evaporation of NAT.

The activation of chlorine is further reflected in the high mixing ratios of $\mathrm{ClO}$ indicated by the model results (Fig. 3). The simulated temporal variation of $\mathrm{ClO}$ is consistent with aircraft [Crewell et al., 1994] and satellite observations [Waters et al., 1993].

Ozone. Previous modeling studies of Arctic ozone depletion [McKenna et al., 1990; Brune et al., 1991; Chipperfield et al., 1993] have simulated significant ozone loss for the lower stratosphere for February 1989 and 1990. Here, we focus on the entire winter of 1991/92. Our model results representative of the polar vortex $\left(78^{\circ} \mathrm{N}-68^{\circ} \mathrm{N}\right.$, corresponding to a total of 300-670 hours of sunlight over the model period) show an integral ozone destruction of $15 \%-38 \%$ in the air parcel (Table 2) in accordance with observed ozone loss rates for the period from mid January to mid February 1992
[Proffitt et al., 1993]. The results of model runs performed for vortex conditions at lower latitudes $\left(58^{\circ} \mathrm{N}\right.$ and $63^{\circ} \mathrm{N}$, Table 2) as a sensitivity study, are consistent with the finding of Brune et al. [1991] that the amount of ozone depletion strongly increases with decreasing latitude. To demonstrate the sensitivity of ozone depletion to the duration of PSC existence, model runs were performed for an unrealistically short (10 days) and long (50 days) PSC periods by shifting temperatures up and down by $3 \mathrm{~K}$ (Table 2). However, in 1992, possibly also unprocessed air masses existed in the vortex [Newman et al., 1993], for which the present analysis is not applicable.

Furthermore, the suggestion by Crutzen et al. [1992], that a cycle involving $\mathrm{R} 10$ and $\mathrm{H} 4$, could be of relevance to Antarctic ozone depletion is extended here to the Arctic (Table 2, Figs. 2 and 3). For the Arctic high latitude ozone loss, this cycle may be of comparable importance as the $\mathrm{BrO}-\mathrm{ClO}$ cycle (Table 2). Since it is strongly dependent on solar illumination [Crutzen et al., 1992], it is triggered earlier during southward excursions if variations in latitude are considered, so that in this case, the $\mathrm{HCl}$ activation, and thus the ozone depletion, is slightly stronger (Table 2, Figs. 2,3).

In a study for the 1991/92 Arctic vortex [Salawitch et al., 1993], the model was initialized with more $\mathrm{ClONO}_{2}$ than $\mathrm{HCl}$ based on in-situ measurements of $\mathrm{HCl}$ [Webster et al., 1993]. Under these circumstances, the complete activation of $\mathrm{HCl}$ proceeds via $\mathrm{H} 3$ and requires no further explanation. Thus, the impact of $\mathrm{H} 4$ and R10 would be reduced. Further, if $\mathrm{H} 2$ does not occur in the stratosphere, as suggested by Webster et al. [1993], the inorganic chlorine reservoir would not be activated completely since any $\mathrm{ClONO}_{2}$ in excess of $\mathrm{HCl}$ would remain unprocessed; consequently, less ozone depletion than for the initialization with excess $\mathrm{HCl}$ employed here is simulated [Salawitch et al., 1993]. In contrast to this view, the $\mathrm{ClONO}_{2}$ profile measured on January 13, $1992[\mathrm{v}$. Clarmann et al., 1993; Oelhaf et al., 1994] indicates that only very little $\mathrm{ClONO}_{2}$ is present in the lower stratosphere during the coldest period of the winter 1992.

\section{Conclusions}

Measurements and model results discussed here yield a consistent picture. Specifically, the activation of chlorine

Table 2. Ozone depletion in percent

\begin{tabular}{cccccc}
\hline lat. & $T-3 \mathrm{~K}$ & $T$ & $T+3 \mathrm{~K}$ & $\mathcal{A}$ & $\mathcal{B}$ \\
\hline $58^{\circ} \mathrm{N}$ & 81 & 60 & 39 & 64 & 45 \\
$63^{\circ} \mathrm{N}$ & 70 & 56 & 33 & 49 & 42 \\
$68^{\circ} \mathrm{N}$ & 49 & 38 & 23 & 28 & 27 \\
$73^{\circ} \mathrm{N}$ & 27 & 23 & 18 & 13 & 15 \\
$78^{\circ} \mathrm{N}$ & 17 & 15 & 14 & 7 & 9 \\
$68^{\circ} \pm 10^{\circ} \mathrm{N}$ & 53 & 42 & 24 & 29 & 30 \\
\hline
\end{tabular}

Ozone depletion simulated in the model from 15.12.91 to 15.3 .92 for temperature $T$ (as in Fig. 1) and with the temperature history shifted upward $(T+3 \mathrm{~K})$ and downward $(T-3 \mathrm{~K})$ by three Kelvin. Further, results are shown from model runs neglecting $\mathcal{A}$ : Reactions $\mathrm{H} 4$ and $\mathrm{R} 10$ and $\mathcal{B}$ : neglecting bromine chemistry. 
during the cold winter period, reflected in balloon-borne measurements of little $\mathrm{ClONO}_{2}$ [v. Clarmann et al., 1993; Oelhaf et al., 1994], aircraft measurements of high concentrations of $\mathrm{ClO}$, low levels of $\mathrm{HCl}$ [Crewell et al., 1994] and large column amounts of OClO [Brandtjen et al., 1994] and ground-based observations of low column amounts of $\mathrm{HCl}$ and $\mathrm{ClONO}_{2}$ inside the polar vortex [Adrian et al., 1994; Bell et al., 1994] is matched by the model results. After the final disappearance of the PSCs, the model shows high column amounts of $\mathrm{ClONO}_{2}$ and an almost complete conversion of active chlorine to $\mathrm{ClONO}_{2}$ (Fig. 2), which remains the dominant inorganic chlorine compound for more than a month, all in accordance with the observations.

Our model results show that reactions $\mathrm{H} 4$ and R10, hitherto omitted in model studies of Arctic ozone loss, may possess a substantial impact on halogen-catalyzed ozone destruction (Table 2). The simulations performed for conditions representative of the lower stratosphere inside the polar vortex for the Arctic winter of 1991/92 indicate, in accordance with observations [Proffitt et al., 1993], that considerable chemical ozone loss may have taken place.

Acknowledgments. We thank Th. Wawers, H. Gimm and T.- $\varnothing$. Gunstrøm for computer support during the campaign and M. Flender for help performing the model runs. Part of this work was funded by the European Community and the German Ministry for Research and Technology (BMFT).

\section{References}

Adrian, G.P. et al., First results of ground based FTIR measurements of atmospheric trace gases in north Sweden and Greenland during EASOE, this issue.

Bell,W. et al., Groundbased measurements of stratospheric constituents over Åre, Sweden, this issue.

Brandtjen, R., Th. Klüpfel, D. Perner, and B. Knudsen, Airborne measurements during EASOE: Observations of $\mathrm{OClO}$, this issue.

Brune, W.H. et al., The potential for ozone depletion in the Arctic polar stratosphere, Science, 252, 1260-1266, 1991.

Burkholder, J.B., R.K. Talukdar, A.R. Ravishankara, and S. Solomon, Temperature dependence of the $\mathrm{HNO}_{3}$ UV absorption cross sections, J. Geophys. Res., in press 1993.

Chipperfield, M.P. et al., A three-dimensional modeling study of trace species in the arctic lower stratosphere during the winter 1989-1990, J. Geophys. Res., 98, 7199-7218, 1993.

v. Clarmann, T. et al., Retrieval of stratospheric $\mathrm{O}_{3}, \mathrm{HNO}_{3}$ and $\mathrm{ClONO}_{2}$ profiles from 1992 MIPAS-B limb emission spectra, $J$. Geophys. Res., 98, 20495-20506, 1993.

Crewell, S., K. Künzi, H. Nett, and P. Hartogh, Aircraft measurements of $\mathrm{ClO}$ and $\mathrm{HCl}$ during EASOE 1991/92, this issue.

Crutzen, P.J., R. Müller, Ch. Brühl, and Th. Peter, On the potential importance of the gas phase reaction $\mathrm{CH}_{3} \mathrm{O}_{2}+\mathrm{ClO} \rightarrow \mathrm{ClOO}+$ $\mathrm{CH}_{3} \mathrm{O}$ and the heterogeneous reaction $\mathrm{HOCl}+\mathrm{HCl} \rightarrow \mathrm{H}_{2} \mathrm{O}+\mathrm{Cl}_{2}$ in "ozone hole" chemistry, Geophys. Res. Lett., 19, 1113-1116, 1992.
DeMore, W.B. et al., Chemical kinetics and photochemical data for use in stratospheric modeling, JPL Publ. 92-20, Pasadena, 185 pp., 1992.

Dye, J., D. Baumgardner, B.W. Ganrud, and R.G. Knollenberg, Particle size distributions in Arctic polar stratospheric clouds, $J$. Geophys. Res., 97, 8015-8034, 1992.

Hanson, D.R., and A.R. Ravishankara, The reaction probabilities of $\mathrm{ClONO}_{2}$ and $\mathrm{N}_{2} \mathrm{O}_{5}$ on 40 to $75 \%$ sulfuric acid solutions, $J$. Geophys. Res., 96, 17307-17314, 1991.

Helleis, F., J.N. Crowley, and G.K. Moortgat, Temperaturedependent rate constants and product branching ratios for the gas-phase reaction between $\mathrm{CH}_{3} \mathrm{O}_{2}$ and $\mathrm{ClO}$, J. Phys. Chem., 97, 11464-11473, 1993.

Lary, D.J., and J.A. Pyle, Diffuse radiation, twilight, and photochemistry, J. Atmos. Chem., 13, 373-406, 1991.

McKenna, D.S. et al., Calculations of ozone destruction during the 1988/89 Arctic Winter, Geophys. Res. Lett., 17, 553-556, 1990.

Naujokat, B., and K. Labitzke, Collection of the reports on the stratospheric circulation during the winters 1974/75-1991/92, STEP, 301 pp., 1993.

Newman, P. et al., Stratospheric meteorological conditions in the arctic polar vortex, 1991 to 1992 , Science, 261, 1143-1146, 1993.

Oelhaf, $\mathrm{H}$. et al., Stratospheric $\mathrm{ClONO}_{2}, \mathrm{O}_{3}$ and $\mathrm{HNO}_{3}$ profiles inside the Arctic vortex from MIPAS-B limb emission spectra obtained during EASOE, this issue.

Proffitt, M.H. et al., Ozone loss inside the northern polar vortex during the 1991-1992 winter. Science, 261, 1150-1154, 1993.

Salawitch, R.J. et al., Chemical loss of ozone in the arctic polar vortex in the winter 1991/92, Science, 261, 1146-1154, 1993.

Schlager, H., F. Arnold, D.J. Hofmann, and T. Deshler, Balloon observations of nitric acid aerosol formation in the arctic stratosphere, Geophys. Res. Lett., 17, 1275-1278, 1990.

Schmidt,U. et al., The variation of available chlorine $\mathrm{ClO}_{y}$ in the Arctic polar vortex during EASOE, this issue.

Stein, B. et al., Stratospheric aerosol sizedistributions from multispectral lidar measurements at Sodanklâ during EASOE, Geophys. Res. Lett., 20, this issue.

Waters, J.W. et al., Stratospheric ClO and ozone from the microwave limb sounder on the upper atmosphere research satellite, Nature, $362,597-602,1993$.

Webster, C.R. et al., Hydrochloric acid loss and chlorine chemistry on polar stratospheric cloud particles in the Arctic winter, Science, 261, 1130-1136, 1993.

P. J. Crutzen, R. Müller, and Th. Peter, Max Planck Institute for Chemistry, Dep. Atmospheric Chemistry, Postf. 3060, 55020

Mainz, Germany (e-mail: muller@nike.mpch-mainz.mpg.de)

Th. v. Clarmann, H. Oelhaf, G. P. Stiller (formerly Adrian), and

A. Wegner, Institute for Meteorology and Climate Research, KFK, Postf. 3640, 76021 Karlsruhe, Germany

U. Schmidt, KFA, ICG-3, Postf. 1913, 52425 Jülich, Germany

D. Lary, Dep. Chemistry, University of Cambridge, Lensfield Rd, Cambridge CB2 1EW, UK

(received November 17, 1992; revised January 24, 1994; accepted February 9, 1994.) 